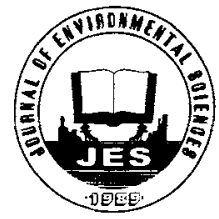

\title{
Inorganic nitrogen removal of toilet wastewater with an airlift external circulation membrane bioreactor
}

\author{
LI Gang, WU Lin-lin, DONG Chun-song, WU Guang-xia, FAN Yao-bo* \\ Research Center for Eco-Enironmental Sciences, Chinese Academy of Sciences, Beijing 100085, China. E-mail: Ligang7786@ 126.com
}

Received 11 December 2005; revised 27 March 2006; accepted 21 April 2006

\begin{abstract}
Removal of inorganic nitrogen (inorganic-N) from toilet wastewater, using a pilot-scale airlift external circulation membrane bioreactor (AEC-MBR) was studied. The results showed that the use of AEC-MBR with limited addition of alkaline reagents and volumetric loading rates of inorganic- $\mathrm{N}$ of $0.19-0.40 \mathrm{~kg}$ inorganic- $\mathrm{N} /\left(\mathrm{m}^{3} \cdot \mathrm{d}\right)$ helped achieve the desired nitrification and denitrification. Furthermore, the effects of $\mathrm{pH}$ and dissolved oxygen (DO) on inorganic-N removal were examined. Under the condition of MLSS at $1.56-2.35 \mathrm{~g} / \mathrm{L}, \mathrm{BOD}_{5} / \mathrm{ammonia}$ nitrogen $\left(\mathrm{NH}_{4}{ }^{+}-\mathrm{N}\right)$ at $1.0, \mathrm{pH}$ at $7.0-7.5$, and $\mathrm{DO}$ at $1.0-2.0 \mathrm{mg} / \mathrm{L}$, the removal efficiencies of $\mathrm{NH}_{4}{ }^{+}-\mathrm{N}$ and inorganic- $\mathrm{N}$ were $91.5 \%$ and $70.0 \%$, respectively, in the AEC-MBR. The cost of addition of alkaline reagent was approximately $0.5-1.5 \mathrm{RMB}$ yuan $/ \mathrm{m}^{3}$, and the energy consumption was approximately $0.72 \mathrm{kWh} / \mathrm{m}^{3}$ at the flux of $8 \mathrm{~L} /\left(\mathrm{m}^{2} \cdot \mathrm{h}\right)$.
\end{abstract}

Key words: inorganic nitrogen removal; treatment of wastewater from toilet; airlift external circulation membrane bioreactor (AECMBR); membrane bioreactor (MBR)

\section{Introduction}

Wastewaters from the toilets, when released into water bodies, are extremely harmful to the aquatic environment because they have high concentrations of suspended solids, uncountable number of microorganisms (including fecal bacteria, pathogenic bacteria, and even viruses) and large quantities of ammonia and organic pollutants (Tananka, 1997; Zeeman and Lettinga, 1999). Once wastewater from toilets is discharged directly into surface waters, serious water pollution occurs and increases the incidence of epidemic diseases. For this reason, the disposal and treatment of wastewater from toilets has always been an important issue of concern in many countries for the prevention of water pollution and protection of water bodies.

To eliminate the pollution caused by wastewater from toilets, various treatment processes, including biodegradation and membrane processes, have been developed to treat the wastewater from toilets. From 1960 to 1970, the main method that was used to treat the concentrated toilet wastewater was to treat the liquid of that diluted approximately 20 times with a process of an anaerobic or an aerobic digestion unit followed by an activated sludge process unit. The two-stage biological denitrification process that involved an approximately 10-time dilution of the wastewater was widely used in the later half of the 1970 s. At the same time, many advanced technologies were applied to treat toilet wastewater, such as combined

Project supported by the Hi-Tech Research and Development Program (863) of China (No. 2002AA601220); *Corresponding author. E-mail: ybfan@rcees.ac.cn. processes involved coagulation sedimentation, ozone oxidation, sand filtration, and activated carbon absorption. In the early 1980s, the first high-load UF membrane separation facility for the treatment of toilet wastewater was put into operation in Japan. From then on, the facilities with membrane and membrane bioreactors (MBRs) were studied and novel facilities were rapidly developed to treat the toilet wastewater (Magara and Itoh, 1991; Magara et al., 1992; Misaki and Matsui, 1996). MBRs were much simple processes that replaced the complex treatment processes incorporated with denitrification, coagulation, filtration, and activated carbon treatment (Magara and Itoh, 1991; Manem, 1996). In recent years, some reports showed that MBRs were used to treat toilet wastewater and gray water on cruise ships, such as the Copa MBR Technology ${ }^{\circledR}$ and the ZeeWeed ${ }^{\circledR}$ MBR of ZENON's system (Bentley and Ballard, 2000; OOZE, 2001).

Ammonia nitrogen $\left(\mathrm{NH}_{4}{ }^{+}-\mathrm{N}\right)$ is an important pollutant in the treatment of toilet wastewater. Although many MBR systems could efficiently eliminate nitrogen, the processes of elimination of nitrogen was always time consuming and complex. MBRs for nitrogen removal from toilet wastewater should have higher nitrogen loading rates, higher nitrogen removal efficiency and lower energy consumption. Since 2000, Xu and Fan (2003) studied the treatment and reuse of toilet wastewater using a novel and simple process named airlift external circulation membrane bioreactor (AEC-MBR). Although a significant reduction in the chemical oxygen demand (COD) $<47$ $\mathrm{mg} / \mathrm{L}$ and biochemical oxygen demand $\left(\mathrm{BOD}_{5}\right)<8.5 \mathrm{mg} / \mathrm{L}$ in the effluent was obtained using the AEC-MBR, the 
ammonia in the effluent, $<20 \mathrm{mg} / \mathrm{L}$, was higher than water reuse standard and the removal efficiency of ammonia, $60 \%-81.9 \%$, was also lower than required. With the establishment of a stricter standard, higher removal efficiency of $\mathrm{NH}_{4}{ }^{+}-\mathrm{N}$ is required and more studies will be necessary to find optimum operation parameters and conditions for obtaining higher removal efficiency of $\mathrm{NH}_{4}{ }^{+}-\mathrm{N}$ from toilet wastewater. However, few studies have been carried out with this objective.

In this study, the removal of inorganic nitrogen (inorganic-N) from toilet wastewater was investigated using an AEC-MBR on a scale of $10 \mathrm{~m}^{3} / \mathrm{d}$. The objectives of this study were to investigate the performance of AEC-MBR, determine characteristics of nitrification and denitrifaction in the AEC-MBR, to examine the effects of operation parameters, such as $\mathrm{pH}$ and dissolved oxygen (DO), on the removal of inorganic- $N$, to determine the optimum values of the operation parameters, and to analyze energy consumption and cost of the AEC-MBR for inorganic- $\mathrm{N}$ removal. In addition, the characteristics of microorganisms in the AEC-MBR were also discussed.

\section{Materials and methods}

\subsection{System description}

Fig.1 shows the pilot-scale AEC-MBR system. The system with a capacity of $10 \mathrm{~m}^{3} / \mathrm{d}$ was installed at a public toilet in Beijing Zoo. The whole system of AEC-MBR mainly comprised the adjustment tank, acidification tank, AEC-MBR tank, and effluent tank, with working volumes of $6.7,7.3,10.2$, and $6.8 \mathrm{~m}^{3}$, respectively, in which the aeration tank and membrane tank composed the AECMBR.

A septic tank was positioned ahead of the AEC-MBR system. From the septic tank, the raw wastewater from the toilet flowed through the acidification tank with filling materials and then into the adjustment tank. A level sensor fixed in the membrane tank was used to switch on the feed pump in the adjustment tank to maintain the water level of the AEC-MBR. In the AEC-MBR, a down-circulation pipe was fixed between the aeration tank and membrane tank. The mixed liquids flowed over the weir between the membrane tank and the aeration tank and then flowed back to the membrane tank through the circulation pipe. The circulation flow of mixed liquids was driven by the density difference between the membrane tank and aeration tank resulting from the air blown from the aeration pipes under the membrane modules. In addition to maintaining circulation, the airflow in the membrane tank created a shear force to scour membrane fibers to control the membrane fouling. The effluent was drawn from the membrane modules and then sent to the effluent tank by a suction pump. A vacuum meter was mounted to monitor the transmembrane pressure (TMP). The total filtration area of hollow fiber membrane modules was $50 \mathrm{~m}^{2}$. Table 1 shows the specifications of the AEC-MBR.

\subsection{Toilet wastewater}

Table 2 shows the characteristics of wastewater from the toilet, which was fed to the AEC-MBR system.

\subsection{Experimental procedure}

In order to enhance the removal efficiency of $\mathrm{NH}_{4}{ }^{+}-$ $\mathrm{N}$ as well as to investigate the effects of $\mathrm{pH}$ and DO on inorganic- $\mathrm{N}$ removal, the experiments were divided into 3 stages for nearly 6 months from Dec. 2003 to Jun. 2004. Table 3 summarized the operational parameters

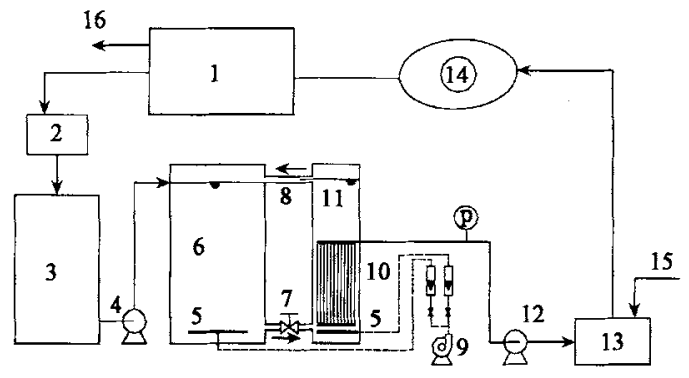

Fig. 1 Schematic of AEC-MBR system for treatment of toilet wastewater (1) septic tank; (2) acidification tank; (3) adjustment tank; (4) feed pump; (5) aeration pipe; (6) aeration tank; (7) circulation pipe; (8) overflow weir; (9) air compressor; (10) membrane modale; (11) membrane tank; (12) suction pump; (13) effluent tank; (14) closestool; (15) tap water; (16) overfalling hole.

Table 1 Specifications of the AEC-MBR

\begin{tabular}{llllll}
\hline Membrane & & Module & & Operation conditions \\
\hline Material & Polyvinylidene fluoride (PVDF) & Surface area $\left(\mathrm{m}^{2}\right)$ & 50 & HRT of the AEC-MBR $(\mathrm{h})$ & 20 \\
Structure of membrane & Hollow fiber & Length $(\mathrm{m})$ & 1.5 & SRT $(\mathrm{d})$ & $30-60$ \\
Pore size $(\mu \mathrm{m})$ & 0.2 & Flux $\left(\mathrm{L} /\left(\mathrm{m}^{2} \cdot \mathrm{h}\right)\right)$ & 8.0 & MLSS $(\mathrm{g} / \mathrm{L})$ & $1.01-2.35$ \\
& & TMP $(\mathrm{MPa})$ & $\leqslant 0.04$ & Load $\left(\mathrm{kg} \mathrm{NH}_{4}+\mathrm{N} /\left(\mathrm{m}^{3} \cdot \mathrm{d}\right)\right)$ & $0.18-0.39$ \\
& & & Load $\left(\mathrm{kg} \mathrm{Inorganic-N} /\left(\mathrm{m}^{3} \cdot \mathrm{d}\right)\right)$ & $0.19-0.40$ \\
& & & Load $(\mathrm{g} \mathrm{COD} /(\mathrm{g} \mathrm{MLSS} \cdot \mathrm{d}))$ & $0.27-0.87$ \\
\hline
\end{tabular}

Table 2 Characteristics of wastewater from the toilet

\begin{tabular}{|c|c|c|c|c|c|c|c|}
\hline & & $\begin{array}{l}\text { COD } \\
(\mathrm{mg} / \mathrm{L})\end{array}$ & $\begin{array}{l}\mathrm{BOD}_{5} \\
(\mathrm{mg} / \mathrm{L})\end{array}$ & $\begin{array}{l}\mathrm{NH}_{4}^{+}-\mathrm{N} \\
(\mathrm{mg} / \mathrm{L})\end{array}$ & $\begin{array}{l}\mathrm{NO}_{2}{ }^{-}-\mathrm{N} \\
(\mathrm{mg} / \mathrm{L})\end{array}$ & $\begin{array}{l}\text { Inorganic-N } \\
(\mathrm{mg} / \mathrm{L})\end{array}$ & $\begin{array}{l}\text { Alkalinity } \\
\left(\mathrm{CaCO}_{3} \mathrm{mg} / \mathrm{L}\right)\end{array}$ \\
\hline \multirow[t]{3}{*}{ Influent } & Max. & 665.2 & 323.3 & 317.6 & 18.3 & 335.9 & 1495.2 \\
\hline & Min. & 211.0 & 149.7 & 149.7 & 1.3 & 151 & 1052.6 \\
\hline & Average & 466.2 & 275.9 & 241.5 & 9.0 & 250.5 & 1283.4 \\
\hline Effluent & Average & 229.5 & 8.81 & 8.31 & 70.26 & 78.57 & 228.5 \\
\hline
\end{tabular}


Table 3 Operation parameters at the three experimental stages

\begin{tabular}{llll}
\hline Experimental stage & I & II & III \\
\hline $\begin{array}{l}\text { Time (d) } \\
\text { Hydraulic retention time (h) }\end{array}$ & $1-56$ & $57-74$ & $75-126$ \\
$\begin{array}{l}\text { Load } \\
\left(\mathrm{kg} \mathrm{NH}_{4}{ }^{+}-\mathrm{N} /\left(\mathrm{m}^{3} \cdot \mathrm{d}\right)\right)\end{array}$ & $0.18-0.35$ & $0.24-0.39$ & $0.29-0.36$ \\
Load & & & 20 \\
$\left(\mathrm{~kg}\right.$ inorganic- $\left.\mathrm{N} /\left(\mathrm{m}^{3} \cdot \mathrm{d}\right)\right)$ & $0.19-0.36$ & $0.23-0.40$ & $0.29-0.37$ \\
$\mathrm{pH}$ & $5.58-6.02$ & $7.0-7.5$ & $7.0-7.5$ \\
$\mathrm{DO}(\mathrm{mg} / \mathrm{L})$ & $5.0-8.1$ & $5.0-8.1$ & $1.0-2.0$ \\
$\begin{array}{l}\text { Sludge concentration } \\
(\mathrm{g} \mathrm{SS} / \mathrm{L})\end{array}$ & $1.01-1.79$ & $1.37-1.95$ & $1.56-2.35$ \\
BOD $/ \mathrm{NH}_{4}{ }^{+}-\mathrm{N}$ & $0.54-1.09$ & $1.5-1.85$ & $1.01-1.45$ \\
\hline
\end{tabular}

at three experimental stages. In the whole experiment, the volumetric loads of $\mathrm{NH}_{4}{ }^{+}-\mathrm{N}$ and inorganic- $\mathrm{N}$ were maintained in a range of $0.18-0.39 \mathrm{~kg} /\left(\mathrm{m}^{3} \cdot \mathrm{d}\right)$ and 0.19 $0.40 \mathrm{~kg} /\left(\mathrm{m}^{3} \cdot \mathrm{d}\right)$, respectively. The $\mathrm{pH}$ of mixed liquid was adjusted by adding alkalinity to the influent of the system and the DO in mixed liquid was controlled by the airflow blew to the aeration tank and the membrane tank.

\subsection{Analysis methods}

The performance of the AEC-MBR system was monitored by the study of the following parameters: COD, BOD 5 , inorganic- $\mathrm{N}\left(\mathrm{NH}_{4}{ }^{+}-\mathrm{N}, \mathrm{NO}_{3}{ }^{-}-\mathrm{N}\right.$ and $\left.\mathrm{NO}_{2}{ }^{-}-\mathrm{N}\right), \mathrm{DO}$, $\mathrm{pH}, \mathrm{MLSS}$, and alkalinity. The samples were taken from influent, mixed liquid, and effluent of the AEC-MBR. The methods and instruments used in the experimental analyses are shown in Table 4.

Table 4 Methods and instruments used for experimental analysis

\begin{tabular}{ll}
\hline Parameter & Methods and instruments \\
\hline COD & CTL-12 COD meter (Huatong Company, China) \\
BOD $_{5}$ & BODTrak' (Hach Company, USA) \\
$\mathrm{NH}_{4}^{+}-\mathrm{N}$ & Nessler's reagent colorimetric method \\
$\mathrm{NO}_{3}{ }^{-}-\mathrm{N}$ & Spectrophotometric method with phenol disulfonic acid \\
$\mathrm{NO}_{2}-\mathrm{N}$ & Spectrophotometric method \\
$\mathrm{DO}$ & Models 810Aplus dissolved oxygen meter (USA) \\
pH & pH meter (pHB-4, China) \\
MLSS & Weight method \\
Alkalinity & Acid-alkaline indicator titrimetric method \\
\hline
\end{tabular}

\section{Results and discussion}

\subsection{Effect of $\mathrm{pH}$ on inorganic- $\mathrm{N}$ removal}

As shown in Fig.2, the nitrogen compounds in the effluent appeared mostly as ammonium nitrogen and nitrate nitrogen. It indicated that the nitrification was not complete during the experimental stage I (1-56 d). In this stage, the average concentration of $\mathrm{NH}_{4}{ }^{+}-\mathrm{N}$ and inorganic- $\mathrm{N}$ in the influent were 241.5 and $250.53 \mathrm{mg} / \mathrm{L}$, respectively. The concentration of $\mathrm{NH}_{4}{ }^{+}-\mathrm{N}$ in the effluent was high and ranged from 57.06 to $79.02 \mathrm{mg} / \mathrm{L}$, with a low nitrification efficiency of $67.5 \%$, and the concentration of inorganic$\mathrm{N}$ in the effluent ranged from 88.54 to $157.32 \mathrm{mg} / \mathrm{L}$, with the average denitrification efficiency of $45.9 \%$. The average concentration of alkalinity (as calcium carbonate $\left(\mathrm{CaCO}_{3}\right)$ ) in mixed liquids was only approximately 283.39
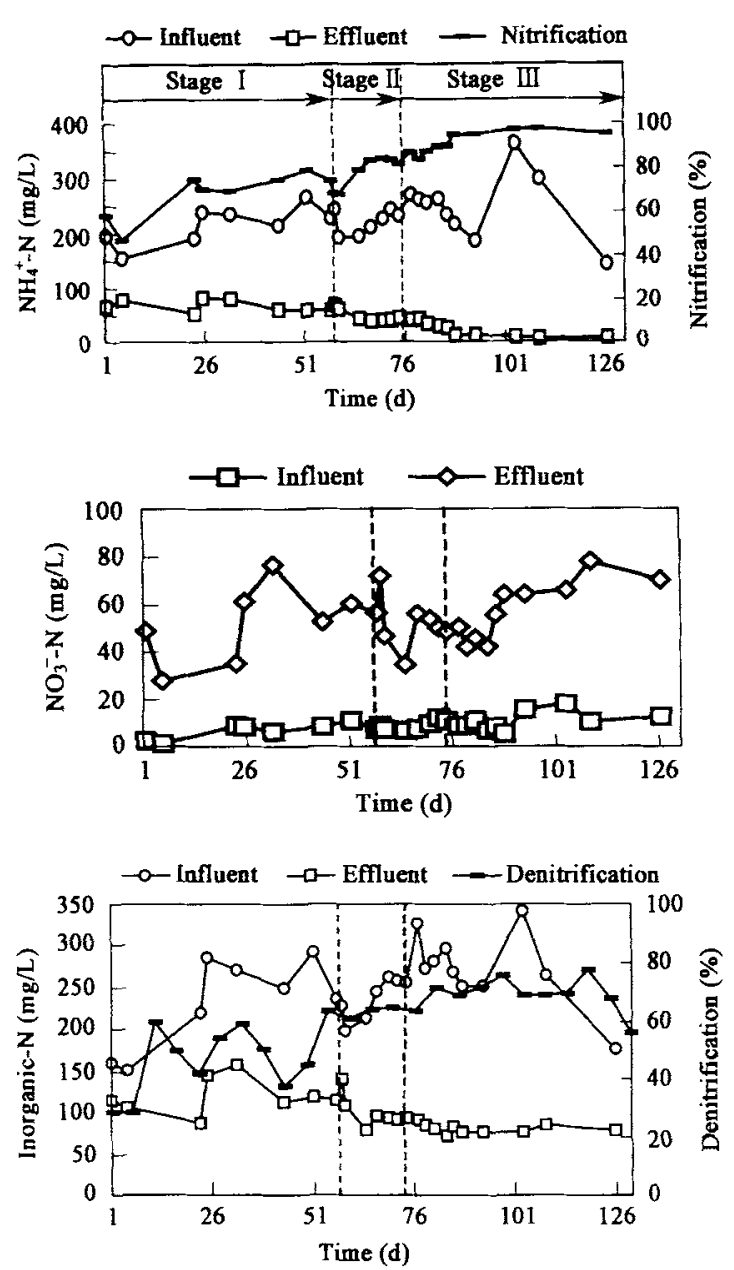

Fig. 2 Variation in $\mathrm{NH}_{4}{ }^{+}-\mathrm{N}(\mathrm{a}), \mathrm{NO}_{2}{ }^{-}-\mathrm{N}(\mathrm{b})$, and inorganic- $\mathrm{N}$ (c) concentration during the experiment.

$\mathrm{mg} / \mathrm{L}$. At the same time, $\mathrm{pH}$ was in the range of 5.735.96. However, according to previous studies (Painter and Loveless, 1983; Toerien et al., 1990), the optimal pH for nitrification was $7.0-8.0$ based on the calculation in theory, and the concentration of alkalinity was more than 2328.46 $\mathrm{mg} / \mathrm{L}$ in the influent. Because of insufficient alkalinity in the influent and the demand of alkalinity for complete nitrification in mixed liquids, it is necessary to increase the alkalinity of the influent to the AEC-MBR. However, the quantity of alkaline reagent added in this type of AECMBR needs to be investigated and determined through experiments.

During experimental stage II $(57-74 \mathrm{~d})$, the effect of $\mathrm{pH}$ on nitrification was investigated. With $\mathrm{pH}$ of mixed liquids in the aeration tank maintained at 7.0-7.5 and with the addition of alkaline reagent, the nitrification was increased obviously, compared with that in experimental stage I. The concentration of $\mathrm{NH}_{4}{ }^{+}-\mathrm{N}$ in the effluent was decreased rapidly from $80-90 \mathrm{mg} / \mathrm{L}$ to $45.25 \mathrm{mg} / \mathrm{L}$, with an average nitrification efficiency of $77.6 \%$, and the average concentration of inorganic- $\mathrm{N}$ in the effluent was $93.79 \mathrm{mg} / \mathrm{L}$, with a removal efficiency of $56.3 \%$ (Fig.2). Furthermore, the concentration of alkalinity (as $\mathrm{CaCO}_{3}$ ) was up to 400 $600 \mathrm{mg} / \mathrm{L}$ in mixed liquids. These results showed that $\mathrm{pH}$ was a very important factor in the nitrification of the toilet wastewater, with higher ammonia concentration and a low 
ratio of carbon to nitrogen $(\mathrm{C} / \mathrm{N})$.

\subsection{Addition of alkaline reagent}

The above results show that alkalinity is an important factor directly affecting the efficiency of nitrification, so the consumption of alkalinity must be determined. To investigate the correlative variation in alkalinity, $\mathrm{pH}$, and $\mathrm{NH}_{4}{ }^{+}-\mathrm{N}$ of the mixed liquids, the beaker test was carried out under the condition simulating experimental stage I. Table 5 shows the correlative variation in alkalinity, $\mathrm{pH}$, and $\mathrm{NH}_{4}{ }^{+} \mathrm{N}$ of the mixed liquids that was obtained using the beaker test; it shows that the final values of alkalinity, $\mathrm{pH}$, and $\mathrm{NH}_{4}{ }^{+}-\mathrm{N}$ are also similar to that obtained during experimental stage $\mathrm{I}$. The variation in $\mathrm{NH}_{4}{ }^{+}-\mathrm{N}$ and alkalinity implies that alkalinity is a key factor for the removal of $\mathrm{NH}_{4}{ }^{+}-\mathrm{N}$ in the AEC-MBR system for treatment of toilet wastewater.

The relationship between $\mathrm{pH}$ and logarithm of alkalinity was obtained through linear regression (Fig.3). The linear equation is as shown in Equation (1), and it can be used as an empirical equation to determine the alkalinity concentration of mixed liquids in the AEC-MBR.

$\mathrm{pH}=4.1377 \mathrm{lg}($ alkalinity $)-3.935$

On the basis of Equation (1), when $\mathrm{pH}$ of mixed liquids was 7.0-7.5, the average concentration of alkalinity (as $\mathrm{CaCO}_{3}$ ) was $400-580 \mathrm{mg} / \mathrm{L}$.

The characteristics of five reagents used to optimize the alkalinity are shown in Table 6 . Commonly, both $\mathrm{CaCO}_{3}$ and sodium hydroxide $(\mathrm{NaOH})$ were used as alkaline reagents in the conventional activated sludge process (Painter and Loveless, 1983; Toerien et al., 1990). However, in the MBRs, although the use of $\mathrm{CaCO}_{3}$ as alkaline reagent is very economical and effective to accommodate the buffering of $\mathrm{pH}$ for nitrification, the accumulation of calcium salts may be a potential hazard to membrane fouling. To avoid membrane fouling resulting from the addition of the alkaline reagent, it is recommended that effective carbonates, sodium carbonate $\left(\mathrm{Na}_{2} \mathrm{CO}_{3}\right)$ or $\mathrm{NaOH}$, be added to rapidly increase $\mathrm{pH}$ without the increase in $\mathrm{Ca}^{2+}$ in the AEC-MBR.

In the AEC-MBR, nitrification-denitrification accompanied the consumption or release of alkalinity. According to the stoichiometry of these biochemical reactions, $1 \mathrm{~g}$ $\mathrm{NH}_{4}{ }^{+}-\mathrm{N}$ consumes $7.14 \mathrm{~g}\left(\mathrm{CaCO}_{3}\right)$ of alkalinity, and 1 g $\mathrm{NO}_{3}{ }^{-}-\mathrm{N}$ releases $3.57 \mathrm{~g}\left(\mathrm{CaCO}_{3}\right)$ of alkalinity, which is half of $\mathrm{NH}_{4}^{+}-\mathrm{N}$ consumption (Toerien et al., 1990; Daigger et al., 1988). In the AEC-MBR, the total alkalinity mainly came from three approaches, such as the influent, addition of alkaline reagents and release of alkalinity during denitrification process, in which the third is a very important aspect to save alkaline reagents for nitrification.

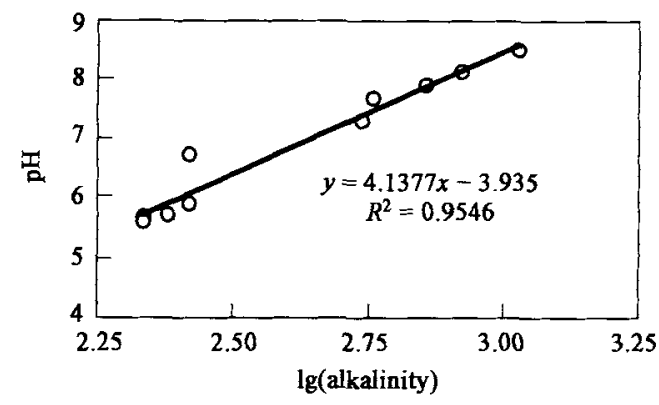

Fig. 3 Linear correlativity of alkalinity with $\mathrm{pH}$.

Fig. 4 shows the ratios of alkalinity $\left(\mathrm{CaCO}_{3}\right)$ to $\mathrm{NH}_{4}{ }^{+}$$\mathrm{N}$ during the experimental stages II and III. The ratio of alkalinity $\left(\mathrm{CaCO}_{3}\right)$ to $\mathrm{NH}_{4}^{+}-\mathrm{N}$ in the influent was approximately 5.20 ( (atio $_{\text {in }}$ ). However, based on the conception of total alkalinity, the ratio of $\mathrm{NH}_{4}{ }^{+}-\mathrm{N}$ should be at $7.32\left(\mathrm{CaCO}_{3}\right)$ for complete nitrification ( ratio $_{\mathrm{co}}$ ). Thus, the ratio of the addition of alkaline reagent was approximately $2.12\left(\mathrm{CaCO}_{3}\right)\left(\mathrm{ratio}_{\mathrm{ad}}\right)$, where the ratio ${ }_{a d}$ is the difference between ratio $\mathrm{co}_{\mathrm{co}}$ and ratio $\mathrm{in}_{\mathrm{in}}$. The amount of alkaline reagent added in the AEC-MBR system can be calculated by ratio ${ }_{a d}$ and concentration of $\mathrm{NH}_{4}{ }^{+}-\mathrm{N}$ in the influent. From the experimental results, if the concentrations of $\mathrm{NH}_{4}{ }^{+}-\mathrm{N}$ in the influent were at $150-300 \mathrm{mg} / \mathrm{L}$, the consumption of alkalinity would be approximately 318 $636 \mathrm{mg}\left(\mathrm{CaCO}_{3}\right) / \mathrm{L}$.

\subsection{Effect of DO on inorganic- $\mathrm{N}$ removal}

The nitrification and denitrification are two main processes involved in inorganic- $N$ removal. Nitrification is an aerobic reaction, the nitrifying cells oxidize ammonia to nitrite or nitrate, demanding oxygen, whereas denitrification is an anaerobic reaction, denitrifying cells reduce nitrite or nitrate to nitrogen under anoxic and anaerobic conditions. In the AEC-MBR, because DO was controlled among $1.0-2.0 \mathrm{mg} / \mathrm{L}$ in the aeration tank and $7.6-9.4 \mathrm{mg} / \mathrm{L}$ in the membrane tank, the recycling of mixed liquids by airlift formed appropriate DO grads inside gel particles

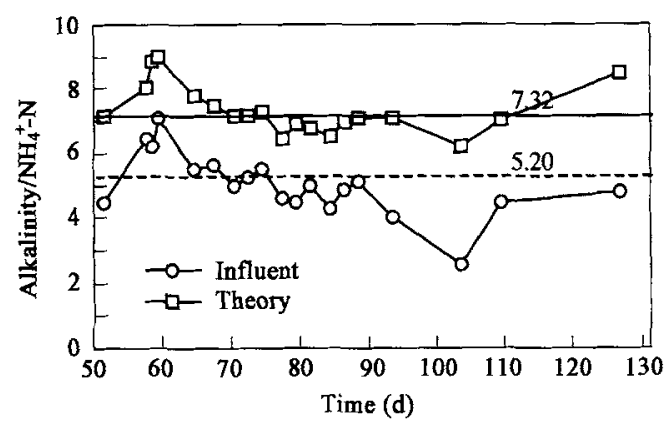

Fig. 4 Ratio of alkalinity to $\mathrm{NH}_{4}{ }^{+}-\mathrm{N}$ during the experimental stages II and III.

Table 5 Variation in alkalinity, $\mathrm{pH}$, and $\mathrm{NH}_{4}{ }^{+}-\mathrm{N}$ observed using the beaker test

\begin{tabular}{lllllllll}
\hline HRT $(\mathrm{h})$ & 0 & 4 & 8 & 10 & 12 & 14 & 16 & 18 \\
\hline $\mathrm{pH}$ & 8.52 & 7.89 & 7.31 & 6.74 & 5.89 & 5.71 & 5.68 & 5.62 \\
Alkalinity $(\mathrm{mg} / \mathrm{L})$ & 1064.61 & 717.72 & 550.25 & 263.16 & 263.16 & 239.24 & 215.32 & 215.32 \\
$\mathrm{NH}_{4}^{+}-\mathrm{N}(\mathrm{mg} / \mathrm{L})$ & 194.62 & 117.96 & 110.2 & 79.62 & 76.1 & 75.66 & 73.01 & 73.01 \\
\hline
\end{tabular}


Table 6 Comparisons of several medicaments as alkalinity

\begin{tabular}{lllll}
\hline Medicament & $\mathrm{pH}$ & $\mathrm{CO}_{2}$ & $\mathrm{HCO}_{3}{ }^{-}$ & $\mathrm{Ca}^{2+}$ \\
\hline $\mathrm{CaCO}_{3}$ & + & - & + & + \\
$\mathrm{NaHCO}_{3}$ & + & $/$ & + & $/$ \\
$\mathrm{NaOH}^{2}$ & + & - & + & $/$ \\
$\mathrm{Na}_{2} \mathrm{CO}_{3}$ & + & - & + & $/$ \\
$\mathrm{Ca}(\mathrm{OH})_{2}$ & + & - & + & + \\
\hline
\end{tabular}

$+:$ increase; -: decrease; /: invariable.

that was one of keys for efficiency of a single-stage biodenitrification process (Cao et al., 2002).

As shown in Fig. 2, the removal efficiency of $\mathrm{NH}_{4}{ }^{+}-\mathrm{N}$ was complete despite the decrease in DO at experimental stage III (75-126 d). Although the concentration of DO reached $1.0 \mathrm{mg} / \mathrm{L}$ in the aeration tank, the concentrations of $\mathrm{NH}_{4}{ }^{+}-\mathrm{N}$ in the effluent were below $10 \mathrm{mg} / \mathrm{L}$, with an average removal efficiency of more than $91 \%$, and the nitrogen compounds in the effluent appeared mostly as nitrate nitrogen. It indicates that nitrification was almost complete during experimental stage III. The concentrations of inorganic- $\mathrm{N}$ in the effluent also decreased from 93.79 to $77.21 \mathrm{mg} / \mathrm{L}$, with an average removal efficiency of $70.0 \%$ after decrease in DO in the aeration tank.

At the same time, when DO was $1.0-2.0 \mathrm{mg} / \mathrm{L}$, the biodegradation of organic contaminants was not effected negatively. The removal efficiencies of $\mathrm{BOD}_{5}$ were maintained above $95.7 \%$ during experimental stage III, as shown in Fig.5.

\subsection{Sludge characteristics}

The specific nitrification rate (SNR), specific denitrification rate (SDNR), and different categories of microorganisms were used to analyze sludge characteristics in mixed liquids. Fig. 6 shows the SNR and SDNR based on the concentration of inorganic- $\mathrm{N}$ in the experiment. It can be seen that the nitrogen removal rate was limited by lower SNR at experiment stage I. Till experimental stage II, the SNR increased sharply from 0.12 to 0.33 $\mathrm{g} \mathrm{NH_{4 }}{ }^{+}-\mathrm{N} /(\mathrm{g} \mathrm{MLSS} \cdot \mathrm{d})$ and the SDNR increased from 0.08 to $0.28 \mathrm{~g}$ inorganic- $\mathrm{N} /(\mathrm{g}$ MLSS.d) when the $\mathrm{pH}$ was maintained at 7.0-7.5 with the addition of alkaline reagent. However, at experimental stage III and at same $\mathrm{pH}$ as that in experimental stage II. the SNR tended toward a drop from 0.33 to $0.13 \mathrm{~g} \mathrm{NH}_{4}{ }^{+}-\mathrm{N} /(\mathrm{g}$ MLSS.d) and the SDNR from 0.28 to $0.08 \mathrm{~g}$ inorganic-N/(g MLSS-d), the main reason for which was the increase in MLSS from 1.56 to

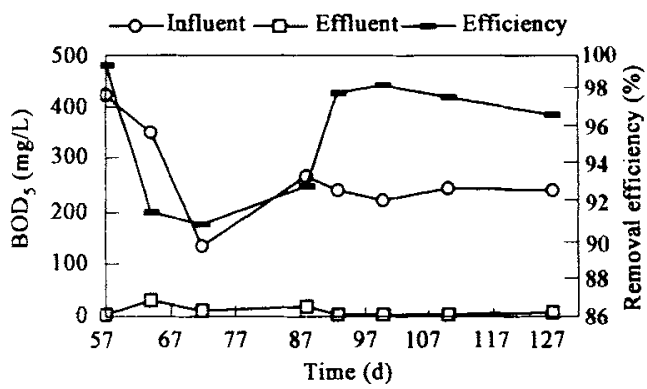

Fig. 5 Variation in $\mathrm{BOD}_{5}$ concentration during experimental stages II and III.

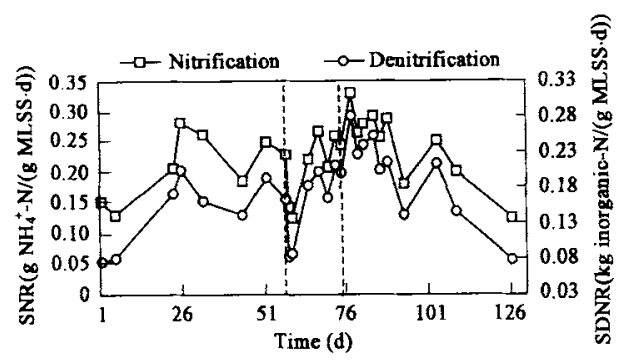

Fig. 6 Velocities of nitrification and denitrification during the experiment.

$2.35 \mathrm{~g} / \mathrm{L}$.

Some reports indicated that it was difficult to find protozoans and metazoans in the MBR systems with external circulation (Zhang and Yamamoto, 1996; Xing et al., 2001). However, in the AEC-MBR, the microorganisms were saved and microbial floc was well maintained because there was no circulation pump in the process. Abundant microorganisms especially subminiature animals were found in the mixed liquids, such as Aspidisca sp., Vorticella sp., Suctoria sp., and Rotifer sp. The microbial communities and their activities were similar to those in the conventional activated sludge processes. Moreover, Aeoloosma hemprichii was also detected, which always survived in the anaerobic condition.

\subsection{Energy consumption and cost analysis}

According to the circulation mode of the AEC-MBR, the energy consumption mainly resulted from air compressor, raw wastewater pump, and suction pump, of which air compressor consumed the largest part of the energy. The energy consumption for air compressor was calculated as shown in Equation (2):

$N=\frac{G \times P}{3600 \times \eta}$

where $N$ is the shaft power of the air compressors, $\mathrm{kW} ; G$ is the airflow rate, $\mathrm{m}^{3} / \mathrm{h} ; P$ is the wind pressure, $\mathrm{kPa}$; and $\eta$ is the available power efficiency of blower, 0.5 .

On the basis of the statistic, $85 \%-94 \%$ of the energy consumption was derived from the aeration. Therefore, the average energy consumption was at $0.72 \mathrm{kWh} / \mathrm{m}^{3}$ at the aeration rate of $18 \mathrm{~m}^{3} / \mathrm{h}$ at the flux of $8 \mathrm{~L} /\left(\mathrm{m}^{2} \cdot \mathrm{h}\right)$ in this experiment. Generally, the energy consumption was $2-10$ $\mathrm{kWh} / \mathrm{m}^{3}$ in the normal external circulation MBRs and 0.2 $0.4 \mathrm{kWh} / \mathrm{m}^{3}$ in the normal submerged MBRs (Zhang and Yamamoto, 1996; Stephenson et al., 2000; Churchouse and Wildgoose, 2002). The energy consumption of AEC-MBR was much lower than that of the normal external circulation MBRs and was close to that of the normal submerged MBRs.

When the concentrations of $\mathrm{NH}_{4}{ }^{+}-\mathrm{N}$ in influent was $100-300 \mathrm{mg} / \mathrm{L}$, with the ratio of alkalinity $\left(\mathrm{CaCO}_{3}\right) / \mathrm{NH}_{4}{ }^{+}-$ $\mathrm{N}$ at 2.12, the consumption of alkalinity will be approximately $212-636\left(\mathrm{CaCO}_{3}\right) \mathrm{mg} / \mathrm{L}$. The cost of addition of alkaline reagent was approximately $0.5-1.5 \mathrm{RMB}$ yuan $/ \mathrm{m}^{3}$ if the price of the alkalinity reagent is $2.5 \mathrm{RMB}$ yuan $/ \mathrm{kg}$. 


\section{Conclusions}

For inorganic-N removal from toilet wastewater, with an AEC-MBR, the SNR, SDNR, and the loads of nitrification and denitrfication, the effect of $\mathrm{pH}$, addition of alkaline reagent, and DO on inorganic- $\mathrm{N}$ removal, the sludge characteristics, energy consumption, and the cost for treatment of toilet wastewater were investigated in this study. The results can be summarized as follows:

(1) In the AEC-MBR, pH was an important factor affecting nitrification and denitrification. The SNR ranged from 0.13 to $0.33 \mathrm{~g} \mathrm{NH}_{4}{ }^{+}-\mathrm{N} /(\mathrm{g} \mathrm{MLSS} \cdot \mathrm{d})$; the SDNR, 0.08 to $0.28 \mathrm{~g}$ inorganic-N/(g MLSS.d); $\mathrm{pH} 7-7.5$; MLSS, $1.56-2.35 \mathrm{~g} / \mathrm{L}$; and DO, $1.0-2.0 \mathrm{mg} / \mathrm{L}$. Under the same conditions as those mentioned above, the removal efficiency of $\mathrm{NH}_{4}{ }^{+}-\mathrm{N}$, total inorganic- $\mathrm{N}$, and $\mathrm{BOD}_{5}$ were $91.5 \%$, $70.0 \%$, and $95.7 \%$, respectively, in the novel type of MBR.

(2) Absence of circulation pump in the circulation model prevented the microorganisms and sludge flocs from being crushed, so that abundant microorganisms especially subminiature animals were found in the mixed liquids, such as Aspidisca sp., Vorticella sp., Suctoria sp., Rotifer sp., and Aeoloosma hemprichii, which played an important role in increasing the removal efficiencies of nitrogen and organic matter.

(3) In AEC-MBR, for the complete removal of $\mathrm{NH}_{4}{ }^{+}-\mathrm{N}$, the ratio for addition of alkaline reagent was approximately 2.12 alkalinity $\left(\mathrm{CaCO}_{3}\right) / \mathrm{NH}_{4}{ }^{+}-\mathrm{N}$. The cost of addition of alkaline reagent was approximately $0.5-1.5 \mathrm{RMB}$ yuan $/ \mathrm{m}^{3}$ if the price of alkalinity reagent was $2.5 \mathrm{RMB}$ yuan $/ \mathrm{kg}$ and $\mathrm{NH}_{4}{ }^{+}-\mathrm{N}$ in the influent was approximately $100-300 \mathrm{mg} / \mathrm{L}$. The energy consumption was approximately $0.72 \mathrm{kWh} / \mathrm{m}^{3}$ at the aeration rate of $18 \mathrm{~m}^{3} / \mathrm{h}$ at the flux of $8 \mathrm{~L} /\left(\mathrm{m}^{2} \cdot \mathrm{h}\right)$.

\section{References}

Bentley A, Ballard I, 2000. Black and gray water treatment solutions using membrane bioreactors[J]. The Naval Architect, 2: 35-41.

Churchouse S, Wildgoos D, 2002. Membrane bioreactors progress from the laboratory to full-scale use[J]. Water Resource, 36(2): 491-500.

Cao G M, Zhao Q X, Sun X B et al., 2002. Characterization of nitrifying and denitrifying bacteria coimmobilized in PVA and kinetics model of biological nitrogen removal by coimmobilized cells[J]. Enzyme and Microbial Technology, 30: 49-55.

Daigger G T, Waltrip G D, Romm E D et al., 1988. Enhanced secondary treatment incorporating biological nutrient removal[J]. J Water Poll Contr Fed, 60: 1833-1841.

Magara Y, Itoh M, 1991. The effect of operational factors on solid/liquid separation by ultra-membrane filtration in a biological denitrification system for collective human excrete treatment plant[J]. Wat Sci Tech, 23(7/8/9): 1583-1590.

Magara Y, Nishimura K, Itoh M et al., 1992. Biological denitrification system with membrane separation for collective human excrete treatment plant[J]. Wat Sci Tech, 25(10): 241-251.

Misaki T, Matsui K, 1996. Night soil treatment system equipped with ultrafiltration[J]. Desalination, 106: 63-70.

Manem J A S, 1996. Membrane bioreactors. In: Water treatment membrane processes (J. Mallevialle, P. E. Odendaal, M.R. Wiesner, ed.). New York: McGraw Hill. 17.1-17.31.

OOZE(OAKVILLE, Ontario, ZENON Environmental Inc.), 2001. Copa submerged membrane bioreactor[EB]. http://www.zenon.ca/investor/news_acrhive.shtml(accessed 7 May 2005).

Painter H A, Loveless J E, 1983. Effect of temperature and pH on the growth-rate constants of nitrifying bacteria in the activated sludge process[J]. Wat Sci Tech, 17: 237-248.

Stephenson T, Judd S J, Jefferson B et al., 2000. Membrane bioreactors for wastewater treatment Alliance House[M]. London: IWA Publishing.

Toerien D F, Gerber A, Lotter L H et al., 1990. Enhanced biological phosphorus removal in activated sludge systems[J]. Advances in Microbial Ecology, 11: 173-230.

Tananka T, 1997. Ultrafiltration aids Japanese treatment[J]. Water Quality International, 7/8: 26-27.

Xing C H, Qian Y, Wen X H et al., 2001. Physical and biological characteristics of a tangential-flow MBR for municipal wastewater treatment[J]. Journal of Membrane Science, 191(1/2): 31-42.

Xu H F, Fan Y B, 2003. Treatment of wastewater from a toilet for reclamation with an airlift external recirculated membrane bioreactor[J]. Environmental Science, 24(2): 125-129.

Zhang B R, Yamamoto K, 1996. Seasonal change of microbial population and activities in a building wastewater reuse system using a membrane separation activated sludge process[J]. Water Science and Technology, 34(5/6): 295302.

Zeeman G, Lettinga G G, 1999. The role of anaerobic digestion of domestic sewage in closing the water and nutrient cycle community level[J]. Wat Sci Tech, 39(5): 187-195. 